\title{
Pengembangan Media Film Sebagai Upaya untuk Menyadarkan Ibu Hamil Mengenai Pentingnya Tes HIV
}

Ratih Indraswari ${ }^{*}$

${ }^{*}$ Fakultas Kesehatan Masyarakat Universitas Diponegoro

Korespondensi : ratih@undip.ac.id

\begin{abstract}
ABSTRAK
WHO memperkirakan bahwa setiap harinya terdapat 1.600 anak-anak yang terinfeksi HIV, atau sekitar 600.000 infeksi HIV baru tiap tahun di seluruh dunia. Penularan melalui perinatal adalah cara penularan yang paling umum terjadi pada anak-anak. Lebih dari 90\% kasus AIDS pada anak ditularkan melalui ibunya yang terinfeksi HIV. Sedangkan tes HIV sebagai satu-satunya cara menegakkan diagnosis infeksi HIV belum banyak diketahui ibu-ibu hamil. Sumber informasi mengenai hal ini pun masih sulit ditemui. Pemakaian media audiovisual terbukti sangat efektif dalam menyampaikan pesan. Selain paparan yang luas karena dapat ditayangkan melalui TV, film sebagai media audiovisual juga dinilai lebih menarik.

Tujuan penelitian ini adalah untuk mengembangkan media promosi kesehatan berupa film untuk menyadarkan ibu hamil mengenai pentingnya tes HIV. Penelitian ini mencakup tahapan analisis kebutuhan media informasi dan pengembangan media. Pada tahap analisis kebutuhan media menggunakan metode review literatur (2 penelitian, 2 buku ilmiah, 3 jurnal ilmiah) dan hasil pretest diperoleh dari wawancara perseorangan. Sasaran adalah ibu-ibu hamil yang merupakan ibu rumah tangga beresiko tinggi tertular $H I V$, tinggal di daerah rural, berpendidikan 9-12 tahun, dan tingkat sosial ekonomi menengah. Film yang diproduksi berjudul "Status" bercerita mengenai seorang suami yang gigih mencari tempat tes HIV untuk istrinya yang sedang hamil. Sebelumnya, rancangan skrip film telah dilakukan ujicoba dan perbaikan sesuai dengan hasil pretest yang didiskusikan dengan para ahli. Film dapat ditayangkan di RS, Puskesmas, Posyandu dan saat melakukan penyuluhan.
\end{abstract}

Kata Kunci : Media, Film, Tes HIV, Ibu Hamil

\begin{abstract}
Developing Movie For Pregnant Women To Aware With Hiv Test; The World Health Organization estimates that, every day, about 1600 children is infected with HIV, or there are about 600,000 new infections annually in children throughout the world. Perinatal $H I V$ transmission is the most common route of HIV infection in children. It is now the source of more than $90 \%$ of all AIDS cases in children. HIV test, as the only way for make sure the diagnosis, is less known by pregnant women. Information sources are also difficult to get. Using audiovisual in sending message is effective. It's huge in reaching people and very interesting as well.

This research was aimed to develop movie for pregnant women to aware with HIV test. Literature review (2 researches, 2 scientific books, 3 journal) method was used to analyze information media need. Pretest was conducted by personal interview. The population of this research was pregnant women with high HIV infection risk who are housewives, lived in rural area, 9-12 study years, and middle socio economic level. The movie titled "Status" which is story a husband who not to yield in finding HIV testing place for his pregnant wife. Before, script was pretested, discussed and revised for betterment product. Film can be played in hospital, health center, and HIV socialization as well.
\end{abstract}

Keywords : Media, movie, HIV test, Pregnant Women. 


\section{PENDAHULUAN}

HIV dapat ditularkan dari ibu yang terinfeksi HIV ke anak selama masa kehamilan, pada proses persalinan, dan saat menyusui. Pada umumnya, terdapat $15-30 \%$ risiko penularan dari ibu ke anak sebelum dan sesudah kelahiran. Semakin tinggi jumlah virus, maka akan semakin tinggi pula risikonya. (KPAN 2008)

WHO memperkirakan bahwa setiap harinya terdapat 1.600 anak-anak yang terinfeksi HIV, atau sekitar 600.000 infeksi HIV baru tiap tahun di seluruh dunia. Penularan melalui perinatal adalah cara penularan yang paling umum terjadi pada anak-anak. Lebih dari 90\% kasus AIDS pada anak ditularkan melalui ibunya yang terinfeksi HIV saat perinatal. Padahal, anak-anak bangsa yang memiliki pendidikan dan status kesehatan yang baik akan dapat menjadi sumber daya manusia yang potensial untuk mendukung pembangunan negara berkelanjutan. Sebaliknya, jika mereka sakit dan tidak segera dilakukan penanganan dan pencegahan penyakitnya, hal itu akan menjadi beban berat bagi negara. (UNAIDS n.d.; Report 2005)

Menurut Departemen Kesehatan RI, tiap tahunnya di Indonesia terdapat 9.000 wanita hamil dengan HIV melahirkan bayinya. Berdasarkan data Organisasi Kesehatan Dunia (WHO) pada 2006, jumlah ibu hamil di Indonesia yang terinfeksi virus HIV positif sebesar 0,6 persen dari 15.000 pengidap HIV/AIDS yang tercatat.(Anonim 2008) Hal ini berarti risiko bayi tertular HIV juga tinggi karena dilahirkan dari ibu yang mengidap HIV.

\section{Statistik Kasus HIV/AIDS di} Indonesia yang dilaporkan sejak 2006 hingga Juni 2009 menunjukkan bahwa kasus penularan HIV melalu transmisi perinatal meningkat. Pada tahun 2006 dan 2007, terdapat 123 kasus secara kumulatif, sedangkan pada Desember 2008 telah mencapai 351 kasus. Pada Juni 2009 saja sudah menunjukkan 443 kasus. Sedangkan menurut jenis kelamin, 3.970 kasus AIDS diidap oleh kaum wanita. Meskipun jumlah wanita yang terinfeksi HIV tidak sebanyak laki-laki dan angka penularan HIV melalui perinatal tidak cukup besar jika dibandingkan penularan melalui hubungan seks dan pemakaian jarum suntik yang tidak steril, dampaknya pada wanita akan selalu lebih besar, baik yang berkembang sebagai masalah kesehatan maupun tantangannya di bidang sosial ekonomi. Wanita memegang peranan penting dalam upaya pencegahan dan perawatan baik untuk mereka yang terkena infeksi maupun untuk penderita AIDS. Wanita juga sangat rentan dan menderita akibat infeksi virus ini.(Depkes RI 2008; Muninjaya 1998) 
Upaya intervensi pengurangan risiko penularan HIV secara perinatal semakin maju. Jika tidak dilakukan intervensi terhadap ibu hamil HIV positif, risiko penularan HIV berkisar antara 25-45\%. Di negara-negara maju, risiko penularan HIV dariibu ke bayi turun menjadi 1-2\% sehubungan dengan majunya tindakan intervensi bagi ibu hamil, yaitu layanan konseling dan tes HIV sukarela. Upaya pengurangan risiko penularan dapat dilakukan melalui konsumsi ARV selama kehamilan, menjalani persalinan dengan operasi caesar, dan pemberian susu formula untuk bayi.(Anon n.d.)

Yayasan Pelita Ilmu (YPI) menyebutan bahwa sejak tahun 2003 hingga Maret 2009, hanya 4.691 (1\%) ibu hamil yang menjalani tes HIV. ${ }^{9,10}$ KPAN melaporkan adanya peningkatan jumlah ibu hamil yang melakukan tes HIV pada bulan Januari hingga Maret 2007, namun angkanya masih rendah yakni 166 ibu hamil secara kumulatif. Bahkan sebagian besar ibu hamil $(89,2 \%)$ tidak berniat untuk melakukan tes HIV. (Komisi Penanggulangan AIDS 2007; Widyawati 2009)

Fakta yang cukup kuat berkaitan dengan tes HIV selama kehamilan adalah pengetahuan ibu hamil mengenai HIV. Masih banyak ibu-ibu yang tidak mengetahui mengenai HIV/AIDS dan cara penularannnya. Hal inilah yang berkontribusi akan tidak dimengertinya masalah kesehatan. Menurut data UNICEF, pengetahuan ibu hamil mengenai cara penularan HIV mencapai $60 \%$, namun hanya $40 \%$ saja yang mengetahui hal-hal apa saja yang tidak menularkan HIV.(Addo 2005; UNICEF 2004)

Pengetahuan yang kurang atau keliru terhadap HIV/AIDS sudah seharusnya diperbaiki agar program penanggulangan dan pencegahan HIV/AIDS menjadia efektif. Untuk itu, pengetahuan dan pemahaman yang akuratt tentang perlunya melakukan tes HIV pada ibu hamil perlu diupayakan untuk diinformasikan agar keluarga menjadi benteng pertahanan dalam upaya pencegahan penyebaran HIV karena dam keluarga tidak hanya ada suami istri namun juga anak-anak sebagai penerus bangsa.(Wartono 1999)

Ruang lingkup atau bidang garapan promosi kesehatan baik secara ilmu (teori) maupun sebagai seni (aplikasi) mencakup berbagai bidang keilmuan lain. Ilmu-ilmu yang dicakup promosi kesehatan dapat dikelompokkan menjadi dua bidang, yaitu ilmu perilaku dan ilmu-ilmu yang diperlukan untuk intervensi perilaku (pembentukan dan perubahan perilaku). Dengan kata lain, dengan adanya promosi kesehatan tersebut diharapkan dapat membawa akibat terhadap perubahan perilaku kesehatan dari sasaran. Promosi kesehatan tidak dapat lepas dari media 
karena melalui media, pesan-pesan yang disampaikan dapat lebih menarik dan dipahami, sehingga sasaran dapat mempelajari pesan tersebut sehingga / sampai memutuskan untuk mengadopsi perilaku yang positif.(Anon n.d.)

Beberapa tujuan atau alasan lain mengapa media sangat diperlukan di dalam pelaksanaan promosi kesehatan antara lain adalah: media dapat mempermudah penyampaian informasi, menghindari kesalahan persepsi, memperjelas informasi, mempermudah pengertian, mengurangi komunikasi yang verbalistik, dapat menampilkan obyek yang tidak bisa ditangkap dengan mata, memperlancar komunikasi dan lain-lain.(Anon n.d.)

Promosi kesehatan tidak ubahnya seperti kampanye produk, memerlukan metode dan sarana penyaluran. Setiap media dan sarana memiliki karakteristik dan kelebihan yang unik. Dalam mengkonsumsi media, berdasarkan hasil riset dari NMR menunjukkan kecenderungan yang hampir persis sama dengan hasil riset dari MarkPlus\&Co, yaitu sebagian besar wanita mengkonsumsi media televisi sebagai media utama (hasil dari NMR adalah 37,02\% dari responden). Menurut Kartajaya et al, 99\% ibu-ibu rutin menonton TV dan menghabiskan waktunya di rumah selama 43 hingga 83 jam tiap minggu.(Levie et al. 1975; Kuswandi 1996) Hal ini sesuai dengan hasil SDKI 1994 yang menyebutkan bahwa sebagian besar ibu mendapatkan informasi mengenai HIV/AIDS dari TV $(34,1 \%)$ dan pada tahun 1997 meningkat menjadi 46,7\%.(Kristanti 1996; KBI GEMARI 2009) Dari data diatas dapat diketahui bahwa paparan TV terhadap para ibu di Indonesia sangat besar sehingga pemanfaatan media audiovisual untuk menyampaikan informasi kesehatan dinilai sangat efektif dan efisien.

Pemilihan media audiovisual sebagai media promosi kesehatan juga didukung dengan berbagai argumen yang menyatakan bahwa media audiovisual banyak dipilih dengan alasan media audiovisual berpengaruh terhadap peningkatan pengetahuan. Alasan lainnya adalah media audiovisual dianggap sebagai sesuatu yang menyenangkan dan membuat rileks.(Amy et al. n.d.; Hubeis 2007)

Media audio visual berupa film mengenai PMTCT pernah dibangakan oleh KPAN dan YPI. Namun tema yang diangkat adalah mengenai prosedur PMTCT, bukan perlunya tes HIV pada ibu hamil. Tes HIV adalah satu-satunya cara menegakkan diagnosis terinfeksi atau tidak sehingga sangat perlu dilakukan oleh ibu hamil. Dengan demikian, upaya pengurangan risiko penularan perinatal dapat dilakukan jika memang ibu hamil telah terinfeksi.(Wartono 1999; Shimp 2004; Dewi \& Nafikadini 2009) 
YPI pernah mengeluarkan media informasi tentang pentingnya tes HIV bagi bu hamil melalui stiker, lembar balik dan leaflet. Padahal, dibandingkan dengan film, media visual seperti tersebut diatas lebih mungkin dibuang atau tidak disimpan oleh sasaran sehingga tingkat efektifitasnya terbilang rendah.(Shimp 2004; Dewi \& Nafikadini 2009)

Penelitian lain menunjukkan bahwa ibu hamil menginginkan untuk mengetahui lebih banyak tentang HIV/AIDS saat melakukan pemeriksaan kehamilan. Namun, para ibu merasa kurang puas dengan jawaban yang diberikan oleh tenaga kesehatan dan merasa malu untuk bertanya lebih jauh lagi. Selain itu, media elektronik dan media massa juga kurang menginformasikan mengenai HIV/AIDS. Padahal ibu rumah tangga banyak menghabiskan waktunya di rumah sehingga tidak terjangkau oleh informasi yang sering dibagikan di tempat kerja, sekolah, atau tempat umum lainnya. ${ }^{12,15}$ Dengan demikian, perlu dilakukan pengembangan media audio visual berupa film untuk menginformasikan pentingnya tes HIV bagi ibu hamil. Pemilihan pengembangan film sebagai media penyampaian informasi didasarkan pada sifatnya yang telah terbukti efektif dan menarik dibandingkan dengan metode penyampaian informasi yang lain.

\section{METODE PENELITIAN}

Penelitian ini merupakan action research, yaitu berupa penerapan teori pembuatan media promosi kesehatan. Penelitian dimulai dengan mengidentifikasi kebutuhan media informasi ibu hamil, kemudian dilanjutkan dengan pembuatan rancangan produk. Setelah itu dilakukan uji coba rancangan produk dan revisi jika diperlukan.

Penelitian dilakukan melalui dua tahap, yaitu tahap identifikasi kebutuhan media informasi dan tahap pengembangan media yang meliputi disain awal produk, pretest produk, dan perbaikan produk. Data pada tahap ini diperoleh melalui review literatur terhadap tulisan-tulisan ilmiah yang berkaitan dengan penelitian untuk mencari keinginan atau selera ibu hamil terhadap media audio visual. Literatur yang direview berjumlah 7 literatur yang berasal dari 2 penelitian, 2 buku ilmiah dan 3 jurnal ilmiah. Semuanya diterbitkan sejak tahun 1999 hingga 2009. Selanjutnya dilakukan analisis deskriptif untuk mengetahui pola mengenai selera ibu terhadap film yang akan dikembangkan. Sedangkan data pada pretest produk diperoleh melalui metode wawancara perorangan terhadap ibu hamil dan review hasil pretest dengan ahli media dan ahli promosi kesehatan yang setelah terkumpul akan dambil kesimpulan umumnya. Pengolahan data dilakukan dengan cara deskriptif isi. 


\section{HASIL DAN PEMBAHASAN}

Identifikasi Kebutuhan Media Informasi

Untuk mencapai tujuan dalam melakukan promosi kesehatan, produsen haruslah memahami sasaran dari produk yang akan dibuat. Semakin memahami dunia sasaran, pengeksekusian konsep akan menjadi lebih mudah dan hasilnya optimal.

Sasaran dari film yang dikembangkan adalah ibu hamil yang berisiko tinggi tertular HIV. Menurut penelitian yang dilakukan Melyana pada ibu hamil risiko tinggi di Kota Semarang, diperoleh karakteristik sebagai berikut: ibu rumah tangga, berumur urang dari 30 tahun, berpendidikan 9-12 tahun, dan tinggal di daerah rural area. Namun data demografis dan geografis saja tidak cukup. Untuk lebih memahami sasaran, data psikografis justru lebih diperlukan.(Widyawati 2009; Kasilo 2008)

Data psikografis dapat dgali melalui 2 pertanyaan utama, yaitu mengenai hal yang paling diinginkan/diimpikan dan hal yang paling ditakutkan terjadi oleh sasaran. Data hasil survey Markplus\&co menunujukkan gambaran nyata bahwa hampir semua ibu di Indosia menginginkan hal yang terbaik untuk anaknya, terutama yang berkaitan dengan pendidikan dan kesehatan anakanak mereka. Anak-anak merupakan strategi jitu untuk mengambil hati ibu. Setelah kebaikan anak, kaum ibu menginginkan kebahagiaan atau keharmonisan keluarga. Setelah 2 hal ini, rumah, mobil baru, dan harta menempati urutan di bawahnya. Sedangkan hal yang paling ditakuti para ibu adalah kebalikannya, yaitu jika sesuatu yang buruk terjadi pada anak dan keluarganya.(Kasilo 2008; Kartajaya 2005)

Berdasarkan hasil riset MarkPlus\&Co terlihat bahwa mayoritas ibu rumah tangga secara total paling menyukai "iklan yang lucu" dengan prosentase total 33\%, kemudian diikuti dengan kategori "pesan yang mudah dimengerti" dengan prosentase sebesar 8,9\% sebagai urutan kategori kedua yang disukai, urutan ketiga adalah " $a d a$ anak-anak lucu yang terlibat" dengan prosentase total $8,7 \%$ dan pada urutan keempat adalah "bintang iklannya terkenal" dengan prosentase total 8,5\%. Dibandingkan dengan unsur lai, keempat unsur ini mendapatkan perolehan poin prosentase tertinggi dan mewakili $59,1 \%$ dari total unsur iklan yang menarik bagi ibu rumah tangga. Bagi pengiklan, apabila ingin membuat iklan yang kemungkinan besar disukai oleh kaum ibu, maka akan lebih mudah bila menerapkan keempat unsur yang menjadi favorit tersebut. Sedangkan unsur lainnya yaitu: iklannya bersifat mendidik (4,9\%), memperlihatkan keluarga harmonis $(4,2 \%)$, tidak berlebihan dan tidak dibuat-buat $(3,9 \%)$, mengandung 
alur cerita $(2,8 \%)$, dan tidak vulgar/sopan (2,7\%).(Levie et al. 1975; Kuswandi 1996)

Desain Media Film

Ibu-ibu hamil sebaiknya melakukan tes HIV untuk mengetahui status HIV-nya, sehingga jika ada yang terbukti positif HIV dapat segera dilakukan pencegahannya agar risiko penularan ke bayi berkurang menjadi 1-2\% saja. Para ibu hamil perlu mendapatkan informasi mengenai hal ini sehingga dikembangkanlah sebuah film yang bertujuan untuk menyadarkan ibu hamil mengenai pentingnya melakukan tes HIV. Untuk menekankan pentingnya tes HIV tersebut, maka peneliti berupaya menceritakan kegigihan seorang ibu hamil dalam mencari tempat yang dapat melakukan tes HIV. Dengan demikian, diharapkan setelah menonton film ini, sasaran akan mengerti bahwa tes HIV u dilakukan untuk memastikan kesehatan diri dan bayinya.

Sesuai dengan hasil dari identifikasi kebutuhan diatas, peneliti ingin menggambarkan sosok ibu yang sangat menyayangi anak yang masih dalam kandungannya. Peneliti juga menampilkan kehidupan keluarga yang dekat dengan kehidupan ibu sehari-hari dimana sebuah keluarga terdiri dari ayah, ibu dan anak meskipun anak disini berarti janin yang akan dilahirkannya.
Berikut adalah sinopsis awal dari film yang akan diproduksi:

Di pinggiran kota, terdapatlah sepasang suami istri (Pak dan Ibu A). Ibu A sedang hamil 2 bulan. Ini adalah kehamilan pertamanya.

Suatu hari, mereka bertamu ke rumah teman mereka (Ibu B) untuk menjenguk anaknya yang sakit. Di rumah Ibu B, ibu A sangat prihatin dengan kondisi anak temannya itu. Ibu B jadi khawatir dengan kondisi janin yang sedang dikandungnya juga.

Esoknya, ibu A ditemani suaminya periksa ke klinik. Disana ia menanyakan tes-tes kehamilan apa saja yang perlu dijalankannya agar bayinya sehat. Dokter menjelaskan berbagai tes-tes kehamilan termasuk tes HIV. Ibu A ingin melakukan tes tersebut namun sayang di klinik itu tidak tersedia karena klinik itu hanya klinik desa.

Ibu A yang semakin cemas mengajak suaminya untuk memeriksakan kehamilannya di klinik kota sekaligus untuk melakukan tes HIV. Di hari mereka pergi ke kota, banyak sekali kendala yang dihadapi. Ibu A sangat kelelahan. Ditengah perjalanan, dia mulai merasakan perutnya sakit. Sangat sakit hingga dia jatuh pingsan.

Saat bangun, dia telah berada di sebuah kamar RS, dia keguguran. Dia sangat sedih dan menangis histeris. 
Pretest dan Perbaikan Disain Media Film

Setelah pembuatan sinopsis, peneliti membuat skrip film yang membantu dalam membayangkan hasil produksi film yang akan dibuat. Skrip adalah bahan yang akan di-pretest-kan. Pretest dilakukan pada 3 orang ibu dimana seorang ibu sedang merencanakan kehamilan dan 2 lainnya sedang dalam kondisi hamil. Responden adalah ibu-ibu rumah tangga berumur 27 hingga 31 tahun. Dua responden adalah tamatan perguruan tinggi dan lainnya adalah tamatan SMA sehingga pemahaman pesan yang berupa gambar dan suara diperkirakan dapat mudah dipahami. Semua responden bertempat tinggal di wilayah rural dan berada pada tingkat sosial ekonomi menengah sehingga sesuai dengan sasaran film yang dikembangkan.

Tabel 1. Hasil Pretest Skrip Film

\begin{tabular}{|c|c|c|c|}
\hline Pertanyaan & Resp 1 & Resp 2 & Resp 3 \\
\hline Tujuan (isi pesan) & $\begin{array}{ll}\text { Ibu hamil perlu } \\
\text { memastikan } & \text { status } \\
\text { HIV-nya } & \end{array}$ & $\begin{array}{llr}\text { Ibu hamil harus bisa } \\
\text { menjaga } & \text { kondisi } \\
\text { kesehatan } & \text { diri } & \text { dan } \\
\text { bayinya } & & \end{array}$ & $\begin{array}{lr}\text { Tes HIV } & \text { perlu } \\
\text { dilakukan } & \text { ibu } \\
\text { hamil } & \\
\end{array}$ \\
\hline $\begin{array}{l}\text { Kemudahan } \\
\text { dipahami }\end{array}$ & Mudah & Cukup mudah & Mudah \\
\hline Alur cerita & Menarik & Menarik & Menarik \\
\hline Durasi & Cukup & Cukup & Cukup \\
\hline Perwatakan & $\begin{array}{l}\text { Suami kurang sayang } \\
\text { dengan istrinya }\end{array}$ & $\begin{array}{l}\text { Suami kurang sayang } \\
\text { dengan istrinya }\end{array}$ & Sudah tepat \\
\hline Yang disukai & Sosok ibu & Kegigihan si ibu & $\begin{array}{l}\text { Ibu yang tegar } \\
\text { dan sayang anak }\end{array}$ \\
\hline $\begin{array}{ll}\text { Yang } & \text { perlu } \\
\text { diperbaiki } & \end{array}$ & $\begin{array}{lr}\text { Akhir cerita yang } \\
\text { menyedihkan dan } \\
\text { cerita keluarga } \mathrm{B} \\
\text { (cerita rumit) }\end{array}$ & $\begin{array}{l}\text { Sosok suami dan akhir } \\
\text { cerita }\end{array}$ & Akhir cerita \\
\hline Keseluruhan & Baik & Baik & Baik \\
\hline
\end{tabular}


Tabel 2. Opini Ahli Terhadap Skrip Film

\begin{tabular}{|c|c|}
\hline & Opini \\
\hline $\begin{array}{l}\text { Ahli promosi } \\
\text { kesehatan }\end{array}$ & $\begin{array}{l}\text { - Sosok ayah perlu diperkuat } \\
\text { - Akhir cerita sebaiknya sesuatu yang membahagiakan } \\
\text { - Cerita keluarga B perlu diringkas }\end{array}$ \\
\hline Ahli media 1 & $\begin{array}{l}\text { - Pencarian tempat tes perlu dipertajam } \\
\text { - Pertimbangan dana dan waktu yang akan dikeluarkan jika } \\
\text { menggunakan banyak tokoh } \\
\text { - Tokoh yang tidak perlu sebaiknya dihilangkan }\end{array}$ \\
\hline Ahli media 2 & $\begin{array}{l}\text { - Pertimbangan jumlah tokoh yang terlalu banyak } \\
\text { - Ikuti keinginan sasaran yang menginginkan pendalaman sosok } \\
\text { suami yang sayang keluarga } \\
\text { - Adegan berulang perlu dihilangkan } \\
\text { - Dialog antar pelakon sudah baik }\end{array}$ \\
\hline Ahli media 3 & $\begin{array}{l}\text { - Suami tidak sepatutnya membiarkan istri yang hamil justru } \\
\text { kelelahan, sehingga kurang sesuai dengan kondisi ideal di } \\
\text { masyarakat } \\
\text { - Buat akhir cerita yang bahagia namun menunjukkan solusi } \\
\text { permasalahan }\end{array}$ \\
\hline Ahli media 4 & $\begin{array}{l}\text { - Mengikuti keinginan sasaran mengenai akhir yang bahagia } \\
\text { - Cerita keluarga B dapat diwakili } 1 \text { pelakon saja }\end{array}$ \\
\hline
\end{tabular}

Setelah dilakukan pretest, sinopsis awal diperbaiki menjadi seperti berikut:

Ali sangat peduli dengan kondisi tetangganya, Ridwan. Ridwan kini tengah depresi sejak kematian istrinya, Liza, yang meninggal akibat AIDS. Kini, Ali sangat mengkhawatirkan status HIV istrinya. Istri Ali, Nora, sedang mengandung namun mereka berdua belum mengetahui status HIV Nora. Ali mengajak Nora untuk melakukan tes HIV dan Nora pun setuju.

Hari berikutnya, Ali berusaha mencari klinik yang memiliki pelayanan tes HIV. Namun, Ali belum juga menemukan tempat itu. Suatu ketika saat Ali sedang beristirahat setelah leleah berjalan mencari klinik, dia bertemu dengan seorang tak dikenal bernama Zulkifli. Pada akhirnya,
Zulkifli inilah yang membantu Ali dan istrinya untuk melakukan tes HIV.

Judul dari film yang dibuat adalah Status karena bertemakan pecarian tempat yang melayani tes HIV dengan tujuan utama yaitu mengetahui status HIV istrinya yang sedang hamil. Sasaran primer film ini adalah ibu hamil yang berisiko tertular HIV dari suaminya, tinggal di rural area, dengan kegiatan sehari-hari sebagai ibu rumah tangga, berpendidikan 9-12 tahun dan termasuk dalam kelas ekonomi sosial menengah. Meskipun demikian, film ini juga dapat digunakan untuk menyadarkan ibu-ibu yang belum atau sedang merencanakan kehamilan mengenai tes HIV yang perlu dilakukan selama kehamilan. Dengan demikian, mereka telah mendapatkan informasi terlebih dahulu 
mengenai pentingnya melakukan tes HIV selama kehamilan.

Tujuan tema film adalah penyadaran ibu hamil bahwa tes HIV penting untuk dilakukan. Berdasar latar belakang sebelumnya bahwa pengetahuan ibu mengenai cara penularan HIV masih rendah. Sedangkan tes HIV adalah satusatunya cara dalam mendiagnosis virus tersebut. Peneliti menggambarkan pentingnya melakukan tes HIV melalui kegigihan seorang suami dan ibu dalam mencari tempat untuk melakukan tes HIV. Kegigihan seorang ibu diartikan sebagai rasa sayang yang mendalam pada buah hatinya bahkan semasa masih dalam kandungan. Selain sesuai dengan realitas sosial di masyarakat, peneliti juga memasukkan unsur empati untuk menggugah emosi penonton sehingga cerita film akan membekas pada benak sasaran usai menontonnya. Salah satu prinsip untuk memenangkan pasar perempuan adalah dengan membawa pesan-pesan emosional. Dengan demikian, mereka akan memiliki keterkaitan emosi terhadap cerita dan isi pesan film karena jika dibandingkan dengan laki-laki, perempuan lebih mementingkan empati.(Kartajaya et al. 2004)

Film yang berdurasi 15 menit ini mengambil cerita pada lingkup keluarga karena keluarga merupakan kelompok terkecil di masyarakat dan memiliki keterikatan hubungan hubungan erat antar individunya. Keluarga yang ditampilkan merupakan contoh dari kelurga harmonis dimana suami dan istri saling menghormati. Hal ini telah disesuaikan dengan keinginan ibu dimana iklan yang disukai sebaiknya merupakan gambaran dari keluarga yang harmonis. Dengan demikian, cerita yang disampaikan sangat dekat dengan kehidupan tiap orang, khususnya dalam hal ini adalah ibu hamil yang merupakan ibu rumah tangga. Penggambaran yang menyerupai realitas sosial akan membuat penonton merasa berempati dan diharapkan mampu mengubah perilaku mereka menjadi perilaku yang diharapkan seperti yang digambarkan dalam film.(Kartajaya 2005; Jowett 1971)

\section{SIMPULAN}

Film berjudul "Status" ingin memberitahu ibu hamil bahwa tes HIV sangat penting dilakukan untuk mencegah terjadinya penularan HIV ke bayi jika si ibu memang terbukti positif HIV. Selain tidak bersifat menggurui, film ini menceritakan seorang suami yang sangat menyayangi istrinya dan ingin memastikan status kesehatan istri dan anaknya dari infeksi HIV. Setelah menonton film ini diharapkan ibu hamil menjdai tahu dan sadar akan pentingnya melakukan tes HIV saat hamil. Disain awal dari skrip film diujicobakan terhadap 3 ibu kemudian hasilnya didiskusikan dengan ahli media dan ahli 
promosi kesehatan. Hasil uji coba kemudian dijadikan sebagai dasar perbaikan film yang meliputi alur cerita dan penokohan tanpa mengubah konsep cerita. Penyuluhan dengan memutarkan film ini dapat dikoordinir oleh Dinas Kesehatan. Durasi film yang pendek memungkinkan pemutaran film dilakukan di Puskesmas dan Posyandu. Film ini juga dapat disebarluaskan dengan memanfaatkan kegiatan organisasi kewanitaan seperti PKK. Lebih jauh, penayangan dapat memanfaatkan media televii dengan menggandeng pihak swasta.

Bagi penelitian selanjutnya yang terkait disarankan melakukan pretest pada 10-20 orang agar hasilnya lebih baik. Retest juga perlu dilakukan untuk mendapatkan hasil yang sesuai dengan situasi dan kondisi sasaran.

\section{KEPUSTAKAAN}

Addo, V., 2005. Pregnant Women's

Knowledge of and Attitudes to HIV

Testing at Komfo Anokye Teaching

Hospital, Kumasi. Ghana Med

Journal, 39(2), pp.50-54.

Amy, B. et al., Reducing

Children'sTelevision-Viewing Time:

A Qualitative Study of Parents and

Their Children. Available at:

http://www.pediatrics.org [Accessed April 28, 2008].
Anon, Prevention Mother to Child Transmission (PMTCT). Available at: http://www.pmtct.net [Accessed February 7, 2009].

Anonim, 2008. PMTCT Mencegah Penularan HIV dari Ibu ke Bayi. Available at: http://www.satudunia.net [Accessed November 14, 2008].

Depkes RI, 2008. Statistik Kasus HIV/AIDS di Indonesia dilapor s/d Desember 2008, Jakarta.

Dewi, R. \& Nafikadini, I., 2009. Laporan Residensi di Yayasan Pelita Ilmu, Hubeis, A., 2007. Pengaruh Desain Pesan Video Instruksional terhadap Peningkatan Pengetahuan Petani tentang Pupuk Agrodyke. Jurnal Agro Ekonomi, 25(1).

Jowett, G. and L.J., 1971. Movies As Mass Communications, London: Sage Publication.

Kartajaya, H., 2005. Winning The Mom Market in Indonesia (Strategi Membidik Pasar Ibu), Jakarta: PT. Gramedia Pustaka Utama.

Kartajaya, H., Yuswohadi, Madyani, D. \& Indrio, B., 2004. Marketing in Venus, Jakarta: Gramedia.

Kasilo, D., 2008. Komunikasi Cinta:

Menembus G-Spot Konsumen

Indonesia, Jakarta: Gramedia.

KBI GEMARI, 2009. Program

Penanggulangan HIV/AIDS Melalui

Pendekatan Ketahanan Keluarga. 
Komisi Penanggulangan AIDS, 2007.

Laporan Lengkap KPA Nasional

Periode Januari - Maret 2007,

Jakarta.

KPAN, 2008. Penularan HIV/AIDS.

Available at:

http://www.aidsindonesia.or.id

[Accessed November 28, 2008].

Kristanti, 1996. Pengetahuan Ibu tentang

AIDS, SDKI 1994. Buletin Penelitian

Kesehatan, 24.

Kuswandi, W., 1996. Komunikasi Massa :

Sebuah Analisis Media Televisi,

Jakarta: PT Rineka Cipta.

Levie, W., Howard \& Levie, D., 1975.

Pictorial Memory Processes. AVCR, 23(1).

Muninjaya, G., 1998. AIDS di Indonesia:

Masalah dan Kebijakan

Penanggulangannya, Jakarta: EGC.

Report, C.M. and M.W., 2005. Introduction of Routine HIV Testing in Prenatal Care- Botswana, 2004. The Journal of the American Medical Association, 293(2).

Shimp, T.A., 2004. Periklanan dan Promosi: Aspek Tambahan Komunikasi Pemasaran Terpadu, Jakarta: Erlangga.

UNAIDS, Fast Facts About HIV. Available at:

http://www.unaids.org/en/Knowledge Centre/Resources/FastFacts [Accessed March 31, 2009].

UNICEF, 2004. Learning to survive: How education for all would save millions of young people,

Wartono, 1999. AIDS Dikenal Untuk Dihindari, Jakarta: LEPIN.

Widyawati, M., 2009. Analisis faktor-faktor yang Mempengaruhi Sikap Ibu Hamil terhadap HIV/AIDS dan VCT di Kelurahan Mangunharjo Kecamatan Tugu Kota SemarangNo Title. Universitas Diponegoro. 